\title{
Franz Rosenzweig's Dialogic Humanism in The Star of Redemption
}

\author{
Mendo Castro Henriques ${ }^{1, *}$
}

\author{
${ }^{1}$ Universidade Católica Portuguesa, Lisbon, Portugal \\ *Corresponding author.Email: mendohenriques@ucp.pt
}

\begin{abstract}
The Star of Redemption (1921) is the major work of Franz Rosenzweig (1886-1927); it is one of the most important books of the 20th century about the problematic of (co)existential philosophy, comparable and opposable to Heidegger's Being and Time (1927). Its purpose may be summed up by saying that human being is born into his own existence through the discovery of absolute Otherness. This New thinking, as Rosenzweig entitled it in a short 1925 essay, created a dialogic humanism alongside the critique of monological thought in the philosophical tradition. One should point out the main co-existential categories of Rosenzweig's proposal and briefly compare his unique point of view as a religious thinker with some main trends of modern and postmodern philosophy.
\end{abstract}

Keywords: Relationship, Dialogue, I/Thou, Alterity, Difference, Narrative, God, Man, World, Creation, Revelation, Redemption.

\section{INTRODUCTION: PANORAMA}

Franz Rosenzweig's major work, The Star of Redemption (1921) is written in an expressionist style with the stated purpose of breaking with the philosophy of totality and creating its own philosophical-theological jargon. A careful reading of a brilliant and highly idiomatic prose is needed to discover what dialogical humanism is; its powerful new thinking was for a long time ignored and only entered the course of ideas in the late 20th century through his disciples Martin Buber and Emmanuel Lévinas [1].

The case must be further considered, because, as a Jewish German, Franz Rosenzweig had the idiosyncratic ingredients to be globally recognized. Yet, fate decided differently. Two world wars and the Holocaust erased from the face of the earth most of the natural heirs of Rosenzweig's work. He, himself, did not seek academic recognition and became a victim of paralysis in 1922, dying seven years later. Else Freund wrote the first monograph on Rosenzweig in 1933. For many years, one main source of his philosophy was Naum Glatzer's brilliant book Franz Rosenzweig; His Life and Thought (1953). Through the 1960s, Rosenzweig became slightly more known by philosophers, theologians, and literary and cultural specialists. What emerged from these studies was a personality who faced the challenges of early 20th century Europe in a lucid and heroic way [2].

Rosenzweig played a brief but notable role in the neo-Hegelian revival in Germany, through his $\mathrm{Ph}$. Diss. Hegel and the State. In the years immediately following World War I, he proposed a synthesis of philosophy and theology, which he called the new thinking, (FRANKS; MORGAN, 2000 109-139) an innovative vision of revelation as the appeal of the Other. His reflections on the finitude and temporal contours of human experience had a lasting impact; dialogue between I and Thou presented relationship as constitutive of individuality. He collaborated with Martin Buber on a German translation of the first five books of the Scriptures and directed a Centre for Jewish adult education in Frankfurt that attracted people like Martin Buber, Erich Fromm, Leo Strauss, Walter Benjamin, and Gershom Scholem [3].

The interest in his work arose through both classical and postmodern topics, across various academic disciplines. Spiritually minded scholars and postmodern authors alike were attracted by his categories of otherness, difference, narrative, 
singularity, redemption, creation, and revelation. From the 1980's onwards, he was brought to the fore by the same impulse that promoted European thinkers such as Heidegger, Gadamer, Benjamin, Blumenberg, Foucault, Ricoeur, Lévinas. As an early $20^{\text {th }}$ century author, and an expressionist writer, he challenged the modern philosophical tradition, pointing to the Scriptural sources of Western European thought.

Rosenzweig's reputation also stems from his short and somehow tragic life. His near conversion to Christianity, his return to Judaism, the composition of The Star of Redemption on postcards sent home from the Balkans war front added to the mystery of his life [4]. He abandoned a promising academic career in order to live and teach in the Jewish community in Frankfurt, and made heroic efforts to continue to work after the paralysis that stroke him. His shared his life with a small circle of cousins and friends - Eugen Rosenstock-Huessy, Rudolf Ehrenberg, Hans Ehrenberg, and Viktor von Weizsäcker, as well as Martin Buber and Ferdinand Ebner. Despite the full support of his wife Edith Hahn, he died of sclerosis at forty-one.

The Star of Redemption has an old-style flavour of a philosophical system with ethical, aesthetic, and metaphysical implications. It is not a hazard that Rosenzweig discovered in the Hegel Archives and edited, the so-called The oldest system program of German idealism, a 1796 manuscript diversely attributed to Hegel, Schelling and Hoelderlin. The Star also contains a system in which Judaism and Christianity, and somehow Islam, offer glimpses of the redemptive unity of humanity. It is written in an idiom that has disappeared, the idiom of German idealism, transformed by the introduction of Biblical categories. The first part of the Star presents the fundamental elements through which reality manifests itself: man, world and God. The three books of the second part show how these elements develop, namely, through relations of creation, revelation, and redemption. The third part proposes Judaism and Christianity as two paths of redemption.

Through a vicarious religious language, Rosenzweig became a philosopher of the traditional image of God with a postmodern language. For him, religion is the framework in which the drama of humanity unfolds. God did not create religion; he created the world. The word religion hardly occurs in The Star of Redemption. He was hostile to the unctuous spirit of religion, in the Nietzschean sense, and simultaneously he was a profound religious thinker and a believer who changed his life through the revelation of divine love.

\section{COMMON SENSE AND PHILOSOPHY}

After the traumatic experience of the First World War, and to the amazement of his family and friends, Franz Rosenzweig chose to work in adult education. In January 1917 he sent an open letter to Herman Cohen, about the issue of education. The text shows confidence in starting an independent school in the Jewish sphere. He advocated a religious instruction, parallel to the conventional high school structure. Now, working in adult education was an unconventional choice for someone who might have had a career at the University of Berlin. As he explained in a letter, dated 30 August 1920, to his Ph. Diss. mentor, Friedrich Meinecke, he declined a readership at the University of Berlin as he was no longer motivated by scientific curiosity and aesthetic appetite. The only thing I would like to make clear is that scholarship is no longer the centre of my attention, and that my life is under the control of an impulse of which I am too aware to simply designate it, my Judaism. And he concludes: The human being who wrote "The Star of Redemption" has a very different calibre than the author of Hegel and the State.

In 1919, with financial support from his father and the late Herman Cohen, Franz Rosenzweig created an institute for the education of adults, successful in their professions but ignorant of Jewish life (amharatzim). The emancipation of Jews in Europe had brought unimaginable freedoms and opportunities; yet the more liberal were disconnected from Judaism; and the conservative struggled against the $19^{\text {th }}$ century assimilationist tide by using the Torah as a set of formal laws and rigid practices. Neither orthodox nor liberals, according to Rosenzweig, exhausted the path of Judaical religion. It was possible to rediscover a new commitment through dialogical thinking.

Franz Rosenzweig and Edith Hahn settled in Frankfurt-am-Main, in 1920, where Franz founded the Freies Juedisches Lehrhaus. This House of Free Jewish Studies provided an open forum for the discussion of philosophical and sociological issues. Rosenzweig wrote a pamphlet entitled $\mathrm{On}$ Education about his Socratic goals, namely, to ensure the pedagogical fruitfulness of not-knowing [amhaaratzus]; acknowledging one's ignorance is 
the first step to knowledge. The school opened, under Rosenzweig's direction, in the autumn of 1920. The New School [Beit Midrash) distanced itself from traditional institutes and attracted many intellectuals from Weimar Germany. Martin Buber, Eduard Strauss, Ernst Simon, Richard Koch, Rudolf Hallo, and Nehemiah Nobel were teachers. Throughout the 1920s, the Lehrhaus also featured personalities such as Gershom Scholem, Leo Strauss, Siegfried Krakauer, Sy Agnon, Erich Fromm, Bertha Pappenheim, and Leo Loewenthal. Until 1929, hundreds of lectures were given, reaching a maximum of 1,100 auditors in 1923 .

From January to March 1921, Rosenzweig taught an introductory philosophy course at the Lehrhaus. In a parallel seminar, he debated supporting materials for the lectures, especially the writings of German idealism, from Kant to Hegel. His opposition to German idealism, is illustrated by the course's subtitle: On the Use of Healthy Common Sense [Vom Gebrauch des gesunden Menschenverstandes.] The expression common sense is very much in evidence in The Star of Redemption and in the summer of 1921 Rosenzweig prepared a manuscript which he called The Little Book of Sick and Healthy Common Sense [Das Büchlein vom gesunden und kranken Menschenverstand] [5]. (ROSENZWEIG F. 1953) In this lengthy parable, he tells the story of a man paralyzed by philosophical questioning: he does not walk for fear of not having a ground; his eyes do not see for fear it is all a dream; hands do not move for lack of reason. When the philosophy of the absolute takes over the mind and incessantly questions himself what is it? he removes himself from the flow of life that allows life to unfold.

The healthy, common-sense person is confident because he accepts the flow of temporal life and everyday language. Common sense does not ask itself what are things? It implicitly recognizes that beings are disclosed over time, and through development. Common sense does not resort to prejudice or move towards predetermined goals. Not even God is experienced before actual experience, as Franz Rosenzweig tells his mother: The most important thing is not whether a person "believes" in the good God; what matters is that you open all your five senses and observe the facts, at the risk that even the good God can be found among the facts.

In an open letter to Martin Buber - The Builders (1923) - Rosenzweig observes that being a Jew means listening to the divine voice of revelation and relating to law and practice in an authentic, non-ritualistic way. The Law [Gesetz], he writes, may have no religious significance, but it always has the potential to become something more than Gesetz; to become Gebot [commandment]. Likewise, observance of mitzvah (Jewish law) remains a formality unless study and devotion open it to the divine. The sacred should not be defined in opposition to the profane, nor the I/Thou in opposition to the I/Him, nor the law in opposition to commandment. The dialogic philosophy is not just a series of sweeping I/Thou experiences. It requires the hard and constructive work of studying languages and acquiring knowledge.

In the fall of 1921, Rosenzweig reported symptoms of a nervous system disorder. In February 1922, despite being diagnosed with Amyotrophic Lateral Sclerosis (ALS) or LouGehring disease, he continued to devote himself to the Lehrhaus; but as early as the spring of 1922, he was limited by garbled speech and writing difficulties. In late summer of 1922, Rudolf Hallo began to help Rosenzweig as director of the institute. By the end of 1922, Rosenzweig could no longer write. In the spring of 1923, the family acquired a special typing machine that allowed him to indicate the letters - and later only the first letters - of the words he wanted to communicate, using a lever to move a dial to the desired letter. As he became incapacitated, his wife Edith aided him more and more. Edith guessed the word intended by Franz from the indication of the first letter. This affection and dedication allowed Franz to continue to communicate with people and write until the moment of death.

\section{CATEGORIES OF ROSENZWEIG'S DIALOGIC THINKING}

In Franz Rosenzweig's thought, the relationship between philosophy and theology it is not always clear. As his conceptual tools are mainly extracted from the Scriptures, there arises the problem of the autonomy of philosophy and theology: miracle and prayer exceed the limits of reason. He uses the Judeo-Christian vocabulary to describe the experience of revelation without which it is impossible to speak of creation and redemption and states that revelation takes place in every cultural world [6]. From this ground emerge the coexistential categories of Rosenzweig's dialogic philosophy that presents life from the unique point 
of view of the Other, as we experience reality through our singularity [7].

\subsection{Relationship}

The fundamental elements of reality are revealed through life, not through reason; they are revealed by relationships, and not by what things are in themselves. Concrete existence, as everything that is unique, is not reached by deduction or induction but by relation. It is relationship that breaks human seclusion, heightened by the fear of death. Relationship is not a product of thought, but an effect of overflowing life; that is the miracle of miracles, the original fact of creation. God enters relationship with man, and man with the world. The relationship fulfilled by life is neither a formal connection nor an abstract synthesis. Between God and the World, the relationship is called creation. Between God and Man, it is revelation. Between Man and the World, it is redemption. The word and designates the ground of experience.

\subsection{Alterity}

It is the relationship between I and Thou [Ich und $D u$ ]. The soul, the apex of the I, is not selfconstituted, but arises from Thou, the other: heteronomy is more relevant than autonomy. Rosenzweig illustrates this priority of Thou over I, with the biblical question addressed in Genesis to Adam [humanity] Where are Thou? From his hiding place, Adam replies: Am I responsible? Rosenzweig's reading of Genesis shows that human being becomes a soul when awakened through dialogue with the divine Thou; the moral subject is constituted when he admits his responsibility, not when he protests his innocence. Subjectivity is not based on autonomy, but on the responsibility to which we are called. We discover ourselves by being with others, that is, we recognize ourselves in the presence of the other.

\subsection{Love}

The revelation of love waits for a redemptive human response: to dedicate oneself to one's neighbour. To love others is to redeem the world and prepare the Kingdom. Redemption is the work of a unique and mortal being who participates in eternity: The fact that each moment can be the last one, makes it eternal. Death is possible at any moment, but love is as strong as death. Revelation means love. And God's love for human uniqueness is a commandment. Contrary to what Kant proposed, love can be ordered; it is the only emotion that can be transformed into a command. Only love can command love. True love manifests itself as a commandment, and it is the imperative par excellence, the only imperative through which human beings redeem the world.

\subsection{Singularity}

Singularity or uniqueness results from the awareness that each human being faces the whole. The break with totality and with the philosophical tradition of essentialism prizes the uniqueness of all the people who exist. This stance was inherited from thinkers such as Schopenhauer, Kierkegaard, and Nietzsche. Rosenzweig adds his own contribution, without losing sight of the strength and consistency of an interpretative system. For Rosenzweig, the categories that express the protest of subjectivity against the system, emerge and gain meaning inside a community. A real community of love is different from nations and states presented by the philosophies of totality. Churches should define themselves by affirming the infinite uniqueness that exists in each of its members and not by the limiting institution. Truly religious life overcomes borders and prejudices. The meaning of human experience is not found in universal history.

\subsection{Finitude}

The anticipation of death is the first statement of human uniqueness. According to German idealism - that Rosenzweig repudiates - a totality never dies as the fate of the individual is indifferent: a human being who belongs to such totality is nothing. By contrast, in dialogic thought, the presence of death should not be feared as it is a sign of the individuality of every living being. Despite all the idealistic efforts to annul death, human anxiety is able to deny pious lies or technological and transhumanistic endeavours. The anticipation of death leads to liberation from the whole. Whoever questions himself, abandons totality and recognizes himself as free.

\subsection{Difference}

Humanity, World and God are autonomous entities, with radical differences; we must embrace difference to get a non-totalitarian vision of the whole. As Rosenzweig expressively writes: reality is like an onion: for each peeled layer, a different layer emerges. Like humanity, the two other 
primordial elements - God and World - also stand out for their uniqueness. The postmodern fracture prevents the reduction of God, Man and World to one another; only in the world there is full nature; full divinity exists only in God; only in man, there is full humanity. Each of these entities triggers a level of discovery indicated by the prefix meta. Thus, there is a metaethical human being, a metalogical world, and a metaphysical God. Traditional philosophy was focused on the question what is? The Ancients reduced God and Human Being to the World, the cosmological point of view. The Middle Ages reduced human being and the world to God, a theological perspective. Modernity reduced the world and God to man, an anthropological perspective.

\subsection{Temporality}

Rosenzweig emphasizes the experience of temporality, a quality of human experience that divides reality into moments. We experience the world as an already-here; our past is creation. We awaken to individuality as present experience; such is the experience of revelation. We share our openness in relationships with others, creating a future; that is redemption. Temporality, thus, is not interpreted as a homogeneous form of sensibility, but as a concrete form determined by events. Temporality is embedded in speech and, thus, the past comes to us in a monologue. As we are immersed in the present, dialogue is the form of revelation. The language of hope is a choir that looks to the future. Time means ability to anticipate a conversation. As thought unfolds in time, we overcome the paralysis. Temporality requires patience. We experience the world as an alreadyhere; our past is creation. We awaken to individuality as a present experience; this is revelation. We share our openness in relationships with others, creating a future; this is called redemption. Thus, in the movement of uniqueness recognized as love, we are in touch with eternity.

\subsection{Language}

The new thinking replaces timeless methods with dialogue. The monological thinker - whether from scholastic, dialectical, analytical, or phenomenological methods - knows by anticipation what to say and is just looking for the best formulation. He has a closed mindset in so far as he is not involved with anyone, as in Plato's written dialogues where the objections are already known beforehand. The experience of time enables us not to anticipate the conversation; authentic thought is fuelled by what is unexpected in life. In true dialogue, we do not know what the other is going to ask or answer; in fact, we do not even know how far we will be led. Dialogue is the expressive mode of language in the present. The speaker needs to complete himself through the other; the listener in the narrative (past), the interlocutor in the conversation (present), and the recipient in the choir's appeal (future).

\subsection{Narrative}

The old thought is characterized by logic, the new thinking by grammar. While thought does not require the other, talking does require someone to talk to. Obviously, narrative thinking remains a thought: it requires the presence of others who not only listen but also speak. Rosenzweig acquired this concept of narrative through Schelling. And so important was it, that, in a letter to his cousin Hans Ehrenberg, he states that if Schelling had completed The Ages of the World, (2000) the Star would have no merit. The three parts of the Star reflect Schelling's so-called second philosophy [8]. The first two parts develop, respectively, Schelling's proposals of negative philosophy and positive philosophy. In the third part the narrative unfolds the life of communities - Jewish and Christian that discovered otherness and communicated such discovery through a narrative and liturgy about creation, revelation, and redemption.

\subsection{Creation}

For Rosenzweig, creation is a form that is also a fact - die Tatsache - insofar as it results from the unifying relationship between the nature (Sache) of the divine creator and the active existence (Tat) of the world. What he calls God's free active pole (God as creator) - the origin of being before big bang — becomes the essential ground for the existence of the world which, in turn, emerges from the reversal of the essential pole (God as created) in the elementary world. The union forged in the creation of divine affirmation and mundane negation has the same factual character as the relationship between being and non-being in each element, life, and death in humanity.

\subsection{Revelation}

It is the moment when subjectivity finds its apex and becomes a soul. A soul is an individual awakened to full existence. This awakening is not 
an intentional act, but the result of divine love for human beings, the presence of the image of God in man. God is the agent that awakens the soul into existence. In book 2 of part II of The Star, the soul feels ashamed for her former unawareness of its singularity as it did not experience yet the love of God. As the experience of divine love is the first step for the self to come out of his initial closure, the second step is to make this love spill over into the human being. The language expresses these moments through the I-Thou dialogue in which man and world walk together.

\subsection{Redemption}

Redemption happens when we can say Thou to an I. The awakened consciousness wants and asks for and hopes for the coming of a better world. The Kingdom of God is the mutual reunion of soul and world, in Rosenzweig's language. Final redemption or forgiveness depends upon the human acknowledgment of the Other. The adequate language will be a choir, which addresses God, praising and asking for the Kingdom, the meeting of human beings and the world within eternity. There is a recognition of the primacy of community, able to express a life in common with God. Redemption, or universal forgiveness, is the product of the free and obedient act of free people united through a love that redeems the world.

\subsection{Verification}

Any philosophical theories, systems and speculations are under suspicion unless we can verify them in life. For Franz Rosenzweig, The Star is just a book, and this work is not a goal, not even a provisional one. The Star was what Rosenzweig called a book-without-sequel, and it concludes with the words: into life. A piece of work - be it a book, a picture, a film, a craft - can be accepted, rejected, criticized, glorified, or ridiculed as it contains statements; as it stands aloof, it is neither true neither false; it needs to be verified in life. The verification or messianic theory of truth guides human beings towards Thou as it asks them to live truth in a relationship. Rosenzweig's new thinking breaks with assumptions about the subjective or objective nature of truth, predominant in philosophical tradition; truth unfolds in relationship, and in the temporality and alterity that introduces eternal life [9].

\section{ROSENZWEIG AND THE PHILOSOPHERS}

Franz Rosenzweig is a modern philosopher with a somewhat post-modern language. There is a foundationalist and Cartesian element in his philosophy. To overcome the doubt about truths found by thought, he seeks to guarantee its veracity in an experience of God as the only reliable source of truth. Although this exteriority of the criterion of truth is intended to overcome the false evidence of truth in philosophical idealism, the solution is hardly acceptable to an unbeliever. There are also Kantian elements: the irreducibility of the ideas of pure reason to thought and the notion that human being is divided between the determinism of nature and metaphysical freedom. He brought from Goethe a commitment to life. Alongside Hegel, he knows that logic is more than pure thought. Schelling's positive philosophy of revelation is very much present: theism, the unity of God, the balance between affirmation and denial of the spirit; and the three stages of the Christian church: Peter's Catholicism, Paul's Protestantism, and the Orthodox Johannes Church.

From the great Western existential thinkers of the $19^{\text {th }}$ century Rosenzweig inherited his new philosophy [10]. Schopenhauer showed him how authentic thought must go beyond a knowledge based on will and at the service of our interests. Kierkegaard showed him that abstract philosophy denies personal spirit. Kierkegaard's devices of fiction and heteronyms are a tool to break the veil of illusion that intoxicates thought with the absurdities of metaphysics. Rosenzweig also envisaged abstract metaphysics as a form of intellectual illness that only common sense can diagnose and cure. From Nietzsche, he captures the abyss between human being and world, experienced to the point of madness. This world is well hidden and there is nothing heavenly in the bosom of being that speaks to man, except under disguise. The whole is difficult to prove; it is harder to get it to talk. The isolation of the human being in the world, a tragic silence, led Nietzsche to existentialism - the first [philosopher], who saw God face to face, if only to deny him [11].

If ever Heidegger had a contemporary, it was Rosenzweig, thus wrote Karl Löwith [12]. The Star (1921) precedes Being and Time (1927) and shows a remarkable anticipation of the question of being. Someone wrote that Der Stern der Erlösung seems like a true Jewish Sein und Zeit avant la lettre. Rosenzweig considers that language simultaneously 
reveals and hides, covers, and discovers, as Heidegger would write years later. Rosenzweig understood time as a specific modality of human experience. Creation, revelation, and redemption, revolving around life, anticipate the three ecstasies of time in Being and Time. For both thinkers, truth is always our truth, but with a difference. Heidegger speaks of truth as unveiling. For Rosenzweig, truth is verification.

These coincidences of both authors are accompanied by profound differences. Heidegger's philosophical space is still dominated by a closed hermeneutics and monologue, a nostalgia of the Pre-Socratics and an obsession for totality. Rosenzweig's dialogic thought radically differs from such a proposal. The Dasein of Being and Time is a monological and totalitarian concept, while, for Rosenzweig, being is relation. For Heidegger, the world is an existential category; on the contrary, Rosenzweig understands the world as a co-existential category, resulting from creationism. For Heidegger, there is project, freedom from death, being in time. In Rosenzweig, we find creation, revelation and redemption, the certainty of eternal life, the presence of the kingdom of God.

Franz Rosenzweig's work evokes Ludwig Wittgenstein since both share a critical attitude towards abstract metaphysics. Wittgenstein repeatedly asserts that the roots of philosophical illusion lie in language. Such similarity is enhanced by the criticism of the search for the essence as a meaningless project, of which we cure ourselves through a return to a common sense use of language. Yet, there is an obvious difference between both: Wittgenstein does not develop a compatibility between religion and grammatical inquiry, while Rosenzweig shows how grammatical method pushes philosophy towards theological thought.

In 1925 Franz Kafka wrote The Castle about which Rosenzweig commented: I have never read a book that reminded me so much of the Bible as The Castle. The inverted story is obvious. The expulsion from paradise, humans without a name (Kafka's heroes only use initials); lost language (no real communication); lost love (only sexuality remains); time as a distorted and paralyzing duration. The three entities of the story - Man (K), the World (village) and God (the castle) - cannot correlate and Rosenzweig picks up the religious question precisely where Kafka left it: the tragic human situation is a consequence of having eaten from the tree of knowledge and not the tree of life.
We are separated from God on both sides: the tree of knowledge separates us from Him; the tree of life separates Him from us [13].

We may compare Rosenzweig with authors with affinities with dialogical thought, such as Lévinas, Ricoeur, and J.L. Marion. Emmanuel Lévinas underlined the primacy of ethics over ontology; [14] he defends the openness to transcendence and universalizes the JudeoChristian experience. He eloquently affirms in his opus magnum Totality and Infinity that Rosenzweig's new thinking is too much imbedded in himself so that he does not have to quote him explicitly.[15] In a 1960 article, he analyses the Star as centred on Jewish identity. Israel's existence as a chosen people gives it responsibility to judge the world in terms of history and revelation. Paul Ricoeur also reveals his religious convictions but claims autonomy for philosophical arguments [16]. J.L. Marion reflects directly upon his religious experience in parallel with Catholic theology assuming his readers understand that.

\section{CONCLUSION}

Rosenzweig's dialogic thinking seeks to understand the whole from the point of view of the finite human being. The Star runs through a cycle of relationships, choosing between everything and nothing, love, and denial. Creation is the selftransforming process of divinity in relation to the world from which human being emerges. Revelation is the self- transforming process of the human being through the relationship with the divine. Redemption is the transformation of the world through the relationship with humanity.

Writing in Germany in the early 1920's, Franz Rosenzweig considered that philosophy was in a turning-point; the idealistic systems of the $19^{\text {th }}$ century represented the last stage of a historical development, initiated by the pre-Socratics. From Jonia to Jena, from Ancient Greek philosophy to the modernity of Hegel, the monological thought predominated. Now it was time for an ecumenical dialogue between philosophy and theology, and between religions themselves. A community that becomes religious through I-Thou relationships anticipates the coming of the Kingdom of God. The language of this reconciliation between eternity and temporality - as in the City of God of St. Augustine, and the Kingdom of Ends in Kant - requires a collaboration between humanities, theology, and philosophy. 
Franz Rosenzweig's existence was a testimony to ecumenical dialogue. His awakening led him to seek fullness in life, and, as the Star's final words say, the path of human life requires eternal life. Eternal life is a formula as contradictory as square circle. The new thinking is designed to overcome such a contradiction as it substitutes essences for relationships. The inexhaustible novelty of the relationship substitutes the closed and totalitarian existence. Redemption is the fact that I learn to say Thou to a Him.

The last words of the Star demand a leap into life, the same leap into life which appeared in his writings On the Use of Healthy Common Sense and The New thinking. After communicating what he finds true, the truth-seeker must be silent not because thought ends, but because it must be continued by others and in other ways. Everyone should philosophize. Everyone should look around their position and situation in life. A book, yet, is never a goal in itself. The goals for which we are responsible arise in everyday life. To acknowledge and live every day as the day of the whole, is necessary to go through a day in the life of the whole. In other words, eternal life is born in time.

In the final lines of the Star, after narrating his vision of what is beyond earthly life, Rosenzweig writes in pages of rare depth and beauty: to where does this door open? You do not know? TO LIFE. [sic]. The last part [Portal) is no longer a part of the book. It is no longer a reading as it is the description of the encounter that allows you to act justly and love tenderly and walk with simplicity with God. The end of the book is a leap into life and the most important thing is to close the book and start living with Thou.

\section{AUTHOR'S CONTRIBUTIONS}

This paper is independently completed by Mendo Castro Henriques

\section{REFERENCES}

[1] BUBER Martin (1971) I and Thou, 1971 New York, Charles Scribner's Sons

[2] MOSES Stéphane (1982) Système et Revelation. La Philosophie de Franz Rosenzweig, Paris, Seuil

[3] AA.VV. (1988) The Philosophy of Franz Rosenzweig. Hanover: Edited by Paul Mendes-Flohr, NH: University Press of New England for Brandeis University Press.
[4] GLATZER Nahum (1953) Franz Rosenzweig: His Life and Thought, New York: Schocken Books

[5] ROSENZWEIG F. (1953) Understanding the Sick and the Healthy: A View of World, Man, and God, tr. e ed. Nahum N. Glatzer, New York: Noonday Press.

[6] HENRIQUES Mendo (2017) Franz Rosenzweig's Dialogical Thought, Lisboa Católica

[7] CHISTYAKOVA Olga (2017) Relationship of Self and Other in Cultural and Religious Communications in Advances in Social Science, Education and Humanities Research, volume 40, 660-664, Atlantis Press

[8] SCHELLING Friedrich (2000) The Ages of the World. Trad Jason M. Wirth . Albany, NY : SUNY Press

[9] POLLOCK Benjamin (2009) Franz Rosenzweig and the Systematic Task of Philosophy, Cambridge, Cambridge University Press

[10] ROSENZWEIG F. (2005) The Star of Redemption, trad. Barbara Galli, Wisconsin, University of Wisconsin Press.

[11] ROSENZWEIG F. (2000) Theological and Philosophical Writings, ed., comm., and notes Paul W. FRANK/Michael L. MORGAN. Indianapolis, Hackett Publishing Company, Inc.

[12] LÖWITH Karl (1966) M. Heidegger and F. Rosenzweig: A Postscript to Being and Time," Nature, History, and Existentialism, and Other Essays in the Philosophy of History. Edit. Arnold Levison. Evanston, IL: Northwestern University Press, 1966, pp. 53-78

[13] KAFKA Franz (1977) Letters to friends, Family and Editors, New York, Schoken Books

[14] BARROS, Nazaré, (2016) "Lévinas; in the beginning was the relation", Jewish Philosophers. Vol. I, Rio de Janeiro, Jaguatirica, 145-161

[15] LÉVINAS Emmanuel, (1961) Totalitét Infini. Essai sur l'exteriorité(Phaenomenologica 8), Haia, Martinus Nijhoff,

[16] RICOEUR Paul (1995) "The 'Figure' in Rosenzweig's The Star of Redemption" Figuring the Sacred: Religion, Narrative, and Imagination. Translated by David Pellauer. Minneapolis, MN: Fortress Press, 1995, pp. 93-107. 